\title{
International Migration in Europe
}

Patterns and Trends since the mid-1990s

John Salt and José Carlos Almeida

\section{(2) OpenEdition}

Journals

Electronic version

URL: https://journals.openedition.org/remi/2828

DOI: $10.4000 /$ remi.2828

ISSN: $1777-5418$

Publisher

Université de Poitiers

\section{Printed version}

Date of publication: 1 July 2006

Number of pages: 155-175

ISBN: 2-911627-42-3

ISSN: 0765-0752

Electronic reference

John Salt and José Carlos Almeida, "International Migration in Europe", Revue européenne des migrations internationales [Online], vol. 22 - $n^{\circ} 2$ | 2006, Online since 01 June 2009, connection on 15 April 2022. URL: http://journals.openedition.org/remi/2828 ; DOI: https://doi.org/10.4000/remi.2828

This text was automatically generated on 15 April 2022.

(c) Université de Poitiers 


\title{
International Migration in Europe
}

\author{
Patterns and Trends since the mid-1990s
}

John Salt and José Carlos Almeida

1 The main aim of this paper is to identify the chief characteristics of European migration flows during the last decade. We do this in terms of a series of questions relating to diversity of the flows and shifts in the patterns and trends. We start by examining whether there have been major changes in stocks of foreign population and whether migration flows in Europe are increasing. We will also review the main origins of foreign migrants and identify the major changes in Europe's migration fields. Finally, we deal with the impact of EU enlargement and conclude by examining the available data on asylum seeking and irregular migration.

2 The lack of data available and the enormous variation from country to country means there is no simple European pattern or trend. Europe is highly geographically differentiated in its physical and human geography and its migrations, not only between east and west, and north and south, but also between adjacent countries. The image of Europe is, therefore, one of diversity. This diversity relates not only to existing flows and trends but also to the methods of registering and measuring them.

Although statistical data provision has immeasurably improved in recent years, the situation remains far from ideal. In Western Europe, the existing data still pose a wide range of problems for the user, arising largely from incompatibility of sources, conceptual and definitional problems. In Central and Eastern Europe and the CIS data availability has improved but methods of collection are still inadequate and there is a lack of well-developed statistical systems. Although considerable strides have been made in some countries in the region, the general picture with regard to data availability is patchy.

4 A fundamental problem is the complexity of migration. For the most part the concepts of migration used as the basis for collecting statistics do not reflect many of the realities of today's movements, characterised as they are by new forms and dynamics. Particularly difficult to capture are short-term movements and status changes as well as, most obviously, illegal migrations. Changes in foreign national stocks do not only reflect the balance of flows and changes of status that result in their incorporation in 
the statistics. Important also are rates of naturalisation which have greater or lesser effects, depending on destination country policies. All this means that the identification of common patterns and trends is difficult, if not impossible.

The following analysis is based on the most recent data available presented in an annual report to the Council of Europe (Salt, 2006) where a more detailed account may be found. It compares the situation of Western Europe, Southern Europe and Central and Eastern Europe. The time-frame used for the analysis is the last decade and the presentation of the data will focus mainly on three different years of the period: one at the beginning of the period, one at the middle and one at the end.

\section{Have There Been Major Changes in Stocks of Foreign Population in Europe Since the mid-1990s?}

6 The total recorded stock of foreign national population living in European countries in 2004 or latest year available (listed in Table 1) stood at around 25.2 million people. Foreign citizens thus appear to constitute some 4.5 per cent of the aggregate population of Europe. The greater part of this foreign stock was resident in Western Europe.

7 Table 1 suggests that in 2004 or thereabouts (using the latest date for which statistics are available) there were around 18.17 million foreign nationals resident in Western Europe. In 1995 the figure for foreign nationals was 17.2 million. Hence, in the period since then, the total foreign national stocks in Western European increased by 5.6 per cent. However, a major difficulty in estimating the size and trend in the number of foreigners is that data for France are available only for 1999 (Census year). In the trend calculation above the same number for France was included in the estimate for both 1995 and 2004. If France is excluded, the percentage change for Western Europe is 6.9 per cent.

8 Southern Europe was the area where the rate of growth was the highest. The number of foreign nationals increased from 1.88 million to 6.24 million. Spain, where the figure multiplied by more than five times from 0.5 million to 2.77 million, was the responsible for much of this increase.

9 By contrast, although most countries in Central and Eastern Europe have experienced some permanent immigration, some of it return migration, flows have been modest and stocks of foreign population remain relatively small. Table 1 indicates that in 2004, or latest year, there were some 1.2 million foreigners recorded as resident in the countries of that region listed representing about 0.5 per cent of a total population of over 242 million. If we exclude Lithuania, Russia and Ukraine, the figure is 888,600 , which compares with 812,000 in 1995 - an increase of around 9.4 per cent. However, information on stocks of foreign population is only slowly becoming available for East European countries and the data in Table 1 are less than comprehensive, derived from a variety of sources, concepts and definitions. In so far as they are based on official sources, they almost certainly underestimate the real total of foreign population currently living in the countries listed. Transit and other temporary migrants, for example, are excluded. 
Table 1: Stock of foreign population in selected European countries, 1995-2004

\begin{tabular}{|l|r|r|r|r|r|r|}
\hline & \multicolumn{3}{|c|}{ (Thousands) } & \multicolumn{3}{c|}{ (Per cent) } \\
\hline & 1995 & 1999 & 2004 & 1995 & 1999 & $2004(1)$ \\
\hline a) Western Europe & & & & & & \\
Austria & & & & & & \\
Belgium (2) & 673,8 & 689,3 & 776,1 & 8,5 & 8,6 & 9,4 \\
Dermark & 909,8 & 897,1 & 850,1 & 9,0 & 8,8 & 8,2 \\
Finland & 222,7 & 259,4 & 267,6 & 4,3 & 4,9 & 5,0 \\
France (3) & 68,6 & 87,7 & 108,3 & 1,3 & 1,7 & 2,0 \\
Germary (4) & 3263,2 & 3263,2 & 3263,2 & 5,6 & 5,6 & 5,4 \\
Iceland & 7173,9 & 7343,6 & 6717,1 & 8,8 & 9,0 & 8,1 \\
Ireland & 4,8 & 7,3 & 10,2 & 1,8 & 2,6 & 3,5 \\
Luxernbourg & 96,1 & 118,0 & 259,4 & 2,7 & 3,2 & 6,4 \\
Netherlands & 132,5 & 152,9 & 174,2 & 32,7 & 35,8 & 38,6 \\
Norway & 725,4 & 651,5 & 699,4 & 4,7 & 4,1 & 4,3 \\
Sweden(5) & 160,8 & 178,7 & 213,3 & 3,7 & 4,0 & 4,5 \\
Switzerland (6) & 531,8 & 487,1 & 481,4 & 6,0 & 5,5 & 5,3 \\
United Kingdom & 1330,6 & 1368,7 & 1495,0 & 19,0 & 19,2 & 22,0 \\
\hline b) Southem Europe & 1914,0 & 2184,0 & 2857,0 & 3,3 & 3,7 & 4,7 \\
Greece (7) & & & & & & \\
Italy (8) & 153,0 & 305,3 & 537,8 & 1,4 & 2,8 & 4,9 \\
Portugal & 991,4 & 1252,0 & 2402,2 & 1,7 & 2,2 & 4,1 \\
Spain (9) & 168,3 & 190,9 & 251,4 & 1,7 & 1,9 & 2,4 \\
Turkey (10) & 499,8 & 801,3 & 2772,2 & 1,3 & 2,0 & 6,5 \\
\hline c) Central and Eastern & 68,1 & 162,2 & 272,9 & 0,1 & 0,4 & 0,4 \\
Europe & & & & & & \\
Bulgaria(11) & 81,0 & 102,2 & 66,4 & 1,0 & 1,2 & 0,9 \\
Czech Republic (12) & 159,2 & 228,9 & 254,3 & 1,5 & 2,2 & 1,9 \\
Estonia (13) & 323,0 & 291,7 & 269,5 & 23,2 & 21,1 & 19,8 \\
Hungary (14) & 140,0 & 153,1 & 143,8 & 1,4 & 1,5 & 1,3 \\
Latvia & 7,1 & 27,6 & 34,9 & 0,3 & 1,2 & 1,4 \\
Lithuania (15) & - & 31,2 & 32,3 & - & 0,9 & 0,9 \\
Poland (16) & 29,9 & 42,8 & 49,2 & 0,1 & 0,1 & 0,1 \\
Romania (17) & 1,9 & 1,3 & 2,5 & 0,0 & 0,0 & 0,0 \\
Russia (18) & 171,6 & - &,- 0 & - & - & - \\
Slovak Republic (19) & 21,9 & 29,5 & 22,1 & 0,4 & 0,5 & 0,4 \\
Slovenia & 48,0 & 42,5 & 45,9 & 2,4 & 2,1 & 2,3 \\
Ukraine & - & - & 290,9 & - & - & 0,6 \\
\hline
\end{tabular}

Notes: (1) Data Source: MRU calculation based on New Cronos Database data - (2) Figure of 2004 refers to 2003 - (3) Figures of both 1995 and 2004 refer to 1999 - (4) The substantial decrease in the number of foreign nationals is the result of the cross-checking of the residential registers and the Central Aliens Register - (5) Some foreigners permits of short duration are not counted (mainly citizens of other Nordic countries) - (6) Numbers of foreigners with annual residence permits (including, up to 31/12/82, holders of permits of durations below 12 months) and holders of settlement permits (permanent permits). Seasonal and frontier workers are excluded - (7) 1999 do not include 0-14 year olds - (8) Figures refer to residence permits - (9) Source: Council Of Europe 2004 demographical development - (10) Figure of 1995 refers to 1996; Figure of 1999 refers to 2000 Census - (11) Stock of long-term resident foreigners, Ministry of Interior - (12) Data derived from Ministries of Labour and Interior, and include only those holding permanent and long-term residence permits - (13) Figure of 1999 refers to 1998; Figure of 2004 refers to 2002 - (14) Temporary residence permit holders only - (15) Figure of 1999 refers to 2001 - (16) Figure of 1995 refers to 1996; figure of 2004 refers to 2002 - (17) Foreign nationals with permanent residence visas - (18) Only permanent resident foreigners, Ministry of Interior, 1998 - (19) Number of residence permits. Source Presidium of Police Corps, in Slovak Correspondent's SOPEMI Report, 2001.

Sources: Council of Europe, National Statistical Offices, OECD SOPEMI Correspondents.

For most Western European countries the current picture is one of relative stability, with either little change or small rises in the most recent statistics. Compared with 1999 only Belgium, Germany and Sweden show falls. In the case of Germany, the substantial decrease in the number of foreign nationals is the result of the crosschecking of the residential registers and the Central Aliens Register. If we compare the figures of 1995 with the figures of 2004, 4 countries show falls and nine shows rises. The countries where the rate of growth was the highest were Ireland, Iceland, Finland and the UK. There are different reasons for these trends, some more general, others specific to individual countries. In the case of the UK a combination of increased labour flows and asylum seeking has raised numbers, while in Ireland's rapid economic growth sucked in foreign workers after 2000.

11 In Southern Europe, much of the rise in Greece, Italy, Portugal and Spain can be attributed to regularisation programmes which have had the effect of converting 
unrecorded migrant stocks into recorded ones. As such, they do not reflect such a large rise in new stocks as might otherwise be surmised. Portugal is the country of this region where the figure of foreign population is the lowest $-251,400$ in 2004 . Nevertheless this represents an increase of around 49 per cent when compared with the figure from 1995.

The situation in Central and Eastern Europe is more varied and more difficult to call because of the inadequacy of the data sources in many cases. Over the period as a whole, three countries had small falls in the stock of foreign population (Bulgaria, Estonia and Slovenia) and three countries had significant rises (Latvia, Romania and the Czech Republic). The other countries had either a small increase or there are no data available to allow comparisons.

It is difficult to generalise from the above but two main observations may be made. First, it is probably true to say that foreign national stocks are continuing to rise: in most countries the trend in the most recent year is upward but for the most part gains are modest. Except for the amnesty countries, there is no evidence of large and sustained increases. Second, there are distinctive geographical variations at work. Countries differ in the rate, direction and timing of change in their foreign populations.

Countries also differ greatly in the proportion of foreigners in relation to the total of their population. In 2004 (or the latest available date) the largest proportions of foreigners, relative to the total population, were in Luxembourg (38.4 per cent of the total population) and Switzerland (22 per cent). In three countries Austria, Belgium (figure from 1999) and Germany (where the absolute figures are the highest), the proportion was around 8-9 per cent. In another group of countries - Denmark, France, Ireland and Sweden - it was around 5-6 per cent. In all other countries of Western Europe listed in Table 1 - Finland, Iceland, the Netherlands, Norway and the United Kingdom - foreign citizens constituted fewer than 5 per cent.

In southern Europe, only Spain has a proportion of foreigners of more than five per cent ( 6.5 per cent). Greece comes next with 4.9 per cent and it is followed by Italy with 4.1 per cent, Portugal with 2.5 per cent and Turkey with 0.4 per cent.

With the major exception of Estonia, all countries in Central and Eastern Europe recorded around 2 per cent or less.

\section{Are Migration Flows Increasing in Europe?}

The data problems mentioned above apply a fortiori to migration flows. Migration flow data for European countries are now more comprehensive than they have ever been, though significant gaps remain. There are still incompatibilities of measurement and definition between countries and this is a particular problem in the former communist countries. Most illegal flows may be assumed to escape the statistical record, although in some individual cases in-movement may occur legally after which the migrant adopts an illegal status. Statistics on emigration are particularly problematical; many countries do not collect them, and those that do tend towards underestimation (Salt, Singleton and Hogarth, 1994). Even in countries with well developed data collection systems, more often than not there are substantial differences between the estimates of a particular flow made by its origin and destination countries respectively. It is still difficult to monitor migration flows involving the countries of Central and Eastern 
Europe although the situation is improving. The recording systems developed during Communist times were designed to record only certain types of flows, mainly those regarded as "permanent", and have proved grossly inadequate for assessing most of the flows that have occurred in the region since 1989. Indeed, many of the categories of movement seen there defy most collection systems regarded as "normal".

It is clear that the lifting of the Iron Curtain heralded increases in migration flows both within and from the region. One estimate is that in the early 1990s the annual average number of officially recorded net migrations from Central and Eastern European countries to western countries was around 850,000 (Garson, Redor and Lemaitre, 1997), compared with less than half this in the three preceding decades (Frejka, 1996; Okolski, 1998). Most emigration during the Communist period was ethnically based, mainly Jews and Germans.

Because statistics for all countries are not available for every year it is impossible to produce an accurate set of annual inflows of foreign population for the whole of Europe. Some countries have no usable data; others have only a partial record. Table 2 again shows big differences between countries in the scale of inflows and outflows. By aggregating the flows for the latest year for the countries listed in Table 2, a best estimate of the current annual recorded flow may be produced. On this basis, the annual flow into Western Europe is about 1.8 million. This compares with 1.4 million in 1995 and 1.4 million in 1999. In Southern Europe there are comparable data only for Portugal and Italy. Aggregating both figures, the result is a growth in the inflows of foreign population from 73,200 in 1995 to 401,900 in 2004 . By contrast, in the CEE countries there was a continuous decrease - from 953,200 in 1995, to 413,100 in 1999 and to 234,100 in 2004. 
Table 2: Flows of foreign population to selected European countries, 1995-2004 (thousands) (1)

\begin{tabular}{|c|c|c|c|c|c|c|c|c|c|}
\hline & \multicolumn{3}{|c|}{ (Inflows) } & \multicolumn{3}{|c|}{ (Outflows) } & \multicolumn{3}{|c|}{ (Net population flows) } \\
\hline & 1995 & 1999 & 2004 & 1995 & 1999 & 2004 & 1995 & 1999 & 2004 \\
\hline $\begin{array}{l}\text { a) Western Europe } \\
\text { Austria (2) } \\
\text { Belgium (3) } \\
\text { Denmark (4) } \\
\text { Finland } \\
\text { Germany (5) } \\
\text { lceland (6) } \\
\text { Luxembourg } \\
\text { Netherlands } \\
\text { Norway (7) } \\
\text { Sweden (8) } \\
\text { Swiberland (9) } \\
\text { United Kingdom (10) }\end{array}$ & $\begin{array}{r}57,1 \\
53,1 \\
39,0 \\
7,3 \\
792,7 \\
0,9 \\
10,3 \\
67,0 \\
16,5 \\
36,1 \\
91,0 \\
228,0 \\
\end{array}$ & $\begin{array}{r}72.4 \\
57.8 \\
26.5 \\
7.9 \\
673.9 \\
1.9 \\
12.8 \\
78.4 \\
32.2 \\
34.6 \\
85.8 \\
337.4\end{array}$ & $\begin{array}{r}97,2 \\
68,8 \\
27,9 \\
11,5 \\
780,2 \\
1,4 \\
11,3 \\
65,1 \\
27,9 \\
47,6 \\
96,3 \\
518,1\end{array}$ & $\begin{array}{r}42,4 \\
33,1 \\
11,1 \\
1,5 \\
567.4 \\
0.7 \\
5.7 \\
21.7 \\
9.0 \\
15,4 \\
69,4 \\
101,0\end{array}$ & $\begin{array}{r}47,3 \\
24,4 \\
16,2 \\
2,0 \\
555,6 \\
1,0 \\
8,0 \\
20,7 \\
12,7 \\
13,4 \\
58,1 \\
151,6\end{array}$ & $\begin{array}{r}46.1 \\
33,9 \\
19,1 \\
4.2 \\
697,6 \\
0.9 \\
9,6 \\
23,5 \\
13.8 \\
16.0 \\
47.9 \\
310,4\end{array}$ & $\begin{array}{r}14.7 \\
20,0 \\
27.9 \\
5.8 \\
225.3 \\
0.2 \\
4.6 \\
45.3 \\
7,5 \\
20.7 \\
21,6 \\
127.0\end{array}$ & $\begin{array}{r}25.1 \\
33.4 \\
10,3 \\
5.9 \\
118.3 \\
0.9 \\
4.8 \\
57.7 \\
19.5 \\
21.2 \\
27.7 \\
185.8\end{array}$ & $\begin{array}{r}51,2 \\
34,9 \\
8,8 \\
7,3 \\
82,6 \\
0,5 \\
1,7 \\
41,6 \\
14,0 \\
31,6 \\
48,4 \\
207,7\end{array}$ \\
\hline \multirow[t]{3}{*}{$\begin{array}{l}\text { b) Southern Europe } \\
\text { Italy (11) } \\
\text { Portugal (12) }\end{array}$} & $\begin{array}{r}68,2 \\
5,0\end{array}$ & $\begin{array}{r}268,0 \\
14,5\end{array}$ & $\begin{array}{r}388,1 \\
13,8\end{array}$ & $\begin{array}{l}8.4 \\
0.2\end{array}$ & $\begin{array}{l}8,6 \\
0,4\end{array}$ & $\begin{array}{r}7,7 \\
10,0\end{array}$ & $\begin{array}{r}59.8 \\
4.8 \\
\end{array}$ & $\begin{array}{r}259.4 \\
14.1\end{array}$ & $\begin{array}{r}380,4 \\
3,8\end{array}$ \\
\hline & \multicolumn{3}{|c|}{ (Inflows) } & \multicolumn{3}{|c|}{$\begin{array}{l}\text { Permanent emigration from } \\
\text { Central and Eastern Europe }\end{array}$} & \multicolumn{3}{|c|}{ (Net population floms) } \\
\hline & 1995 & 1999 & 2004 & 1996 & 1999 & 2004 & 1995 & 1999 & 2004 \\
\hline $\begin{array}{l}\text { (c) Central and Eastem } \\
\text { Europe } \\
\text { Croatia (13) } \\
\text { Czech Republic (14) } \\
\text { Hungary (15) } \\
\text { Latvia (16) } \\
\text { Lithuania (16) } \\
\text { Poland (17) } \\
\text { Romania (18) } \\
\text { Russia } \\
\text { Slovak Republic }\end{array}$ & $\begin{array}{r}42,0 \\
10,5 \\
14,0 \\
2,8 \\
2,0 \\
8,1 \\
4,5 \\
866,3 \\
3,0\end{array}$ & $\begin{array}{r}2.1 \\
7.8 \\
20.2 \\
1.6 \\
1.5 \\
7.3 \\
11.0 \\
359,3 \\
2,3\end{array}$ & $\begin{array}{r}18.4 \\
53,5 \\
21,3 \\
1,7 \\
5,6 \\
7,0 \\
3,0 \\
119,2 \\
4,4\end{array}$ & $\begin{array}{r}15.4 \\
0.5 \\
2.4 \\
13,3 \\
3.8 \\
26,3 \\
4.8 \\
340.0 \\
0.2\end{array}$ & $\begin{array}{r}8,7 \\
1,1 \\
2,5 \\
3,7 \\
1,4 \\
21,5 \\
1,3 \\
215,0 \\
0,6\end{array}$ & $\begin{array}{r}6,8 \\
34,9 \\
3,1 \\
2,7 \\
15,2 \\
20,8 \\
13,1 \\
79,8 \\
1,6\end{array}$ & $\begin{array}{r}26.6 \\
10,0 \\
11.6 \\
-10.5 \\
-1.8 \\
-18.2 \\
-0.3 \\
526.3 \\
2.8\end{array}$ & $\begin{array}{r}-6,6 \\
6.6 \\
17.7 \\
-1.9 \\
0.1 \\
-14,0 \\
9.7 \\
144,3 \\
1,7\end{array}$ & $\begin{array}{r}11,6 \\
18,6 \\
18,2 \\
-1 \\
-9,6 \\
-13,8 \\
-10.1 \\
39,4 \\
2,8\end{array}$ \\
\hline
\end{tabular}

Notes: (1) Asylum seekers are excluded - (2) Figure of 1995 refers to 1996; Figure of 2004 refers to 2003 - (3) Figure of 2004 refers to 2003 - (4) Data Source: National Statistical Offices - (5) Outflow data includes registered exits of asylum seekers - (6) Figure of 2004 refers to 2003 - (7) Entries of foreigners intending to stay longer than six months in Norway - (8) Some short duration entries are not counted (mainly citizens of other Nordic countries). Regarding outflows, some foreign citizens (in particular from other Nordic countries) are not included - (9) Entries of foreigners with annual residence permits, and those with settlement permits (permanent permits) who return to Switzerland after a temporary stay abroad. Seasonal and frontier workers, and transformations are excluded. The outflow figure refers to exits of foreigners with annual residence permits and holders of settlement permits (permanent permits) - (10) Source: International Passenger Survey, ONS. - (11) Figure of 2004 refers to 2002. Regarding Outflow, figure of 2004 refers to 2003 - (12) Figure of 2004 refers to 2003. Regarding Outflows, figure of 1995 refers to 1996; Figure of 2004 refers to 2002 - (13) Outflow data includes only emigrants who report their departure - (14) Immigrants are persons who have been granted a permanent residence permit. Outflow figure Includes only emigrants who report their departure - (15) Regarding Inflows, data refer to foreigners with long-term resident permits or immigration permits, except for foreigners with labour permits. Figure of 2004 refers to 2003. Regrading Outflows, 1997 figure - Source: HCSO. Data refer to foreigners with long-term resident permits or immigration permits, except for foreigners with labour permits. Figure of 2004 refers to 2003 - (16) Recorded as "external" migration flows referring to non-Baltic countries - (17) Immigrants are persons granted a permanent residence permit. Numbers may be underestimates since not all children accompanying immigrants are registered. Figure of 2004 refers to 2003. Regarding Outflows, only persons who register their intention to establish a permanent residence abroad with the authorities are included in statistics. Figure of 2004 refers to 2003 - (18) Inflow data regers to persons granted a permanent residence permit. Outflow data refers to foreign nationals emigrating. Figure of 1995 refers to 1996.

Sources: Council of Europe, National Statistical Offices, OECD SOPEMI Correspondents.

There are fewer data on outflows than inflows. Those countries in Western Europe for which there are data lost 878,400 nationals to emigration in 1995, 911,000 in 1999 and 1.2 million in 2004. Southern Europe (Italy and Portugal) lost 8,600 in 1995, 9,000 in 1999 and 17,700 in 2004. Data for Central and Eastern Europe mostly record permanent emigration. They show that countries in the region lost 406,700 in 1995, 255,800 in 1999 and 178,000 in 2004. 
21 The combination of these in and outflows resulted in a net gain in 2004 (or nearest year) of around 530,300 in Western Europe, 384,200 in Southern Europe and 56,100 in CEE countries, giving a net overall gain of 970,600 (Table 2).

New migrations have appeared. Some of these reflect the emergence of new origin areas. There were an estimated 63,000 Chinese migrants in Germany in 2001, double the figure in 1993 and ten times that of 1988 (Giese, 2003). In Italy, 68,000 residence permits were granted to Chinese citizens in 2001, more than five times that in 1993 (Ceccagno, 2003). Albanians have also been on the move, remittances from them representing the country's main source of external income after aid in the mid-1990s. By 2000, 133,000 of them had permits to stay in Italy (Mai and Schwander-Sievers, 2003).

There is also evidence of new types of flows. Peraldi (2004) describes how over the last ten years Algerian migratory routes have undergone radical change. The traditional labour migration into France has been replaced by forms of circulation in which many Algerians have become suitcase traders throughout the Mediterranean region. Often serving tourist markets, their moves take place within family networks which allow them to seize trading opportunities in whichever city they are presented. Romanians have also been observed to circulate within informal transnational networks which they use to exploit whatever "work niches" are opened to illegal workers (Potot, 2004). There is some evidence, too, that ethnic migrations have been metamorphosed into ones of circulation. Michalon (2004) demonstrates that the migration of ethnic Germans from Transylvania to Germany in the early 1990s has become a circulatory movement with periods of work in Germany interspersed with living back in Romania.

The trends described here are complex and indicate considerable variations from country to country and at different time periods. In the circumstances, explanations will also be complex, related to general economic conditions, stage of economic development reached in the CEE countries, the effects of Balkan wars, individual national policy initiatives, regularisation programmes, levels of asylum seeking and the efforts of smugglers and traffickers, as well as other factors. Even so, it should nevertheless be noted that the trends identified underestimate total flows, since for the most part they exclude asylum seekers and some categories of temporary immigrants, many of whom it is known stay illegally.

\section{Which Are the Main Origins of Foreign Migrants?}

There are broad differences between the foreign populations of Western Europe, Southern Europe and Central and Eastern Europe, as well as individual differences between countries.

The composition of the foreign population in Western Europe is a reflection of successive waves of post-war migration associated first with labour shortage and more recently (especially since the mid-1970s) with family reunion and formation, as well as the flight of refugees from war-torn areas both within and outside Europe. The dominant foreign groups within each country reflect the sources from which labour has been recruited since the war; particular historical links and bilateral relations with former colonies; and ease of access (in terms of geography or policy) for refugees and asylum seekers from different places. Despite their recent status as immigration countries, the largest foreign national groups continue to be from the traditional 
labour recruitment countries of Southern Europe (Italy, Portugal, Spain and Greece), plus Turkey and former Yugoslavia, and more recently North Africa.

Comparative statistics on the national composition of the foreign population are available for years since 2000 for some but not all countries (dates indicated on Table 3 ), but the pace of change of composition is slow enough for them to give a reasonable picture of the current situation. Of particular significance is the number of fellow EEA nationals in member states, since these groups have rights of free movement and are not subject to the same immigration and residence controls as non-EEA citizens.

The data in Table 3 illustrate the existing considerable diversity of foreign migrant origins in Western Europe. In Luxembourg, Liechtenstein, Belgium and Switzerland, over half of the foreign population is from other EU/EFTA countries; for Spain, UK, France and the Netherlands between a third and a half. Around 55 per cent of Switzerland's foreign nationals are EU citizens. For most countries, however, the bulk of their foreign national population comes from outside the EU/EFTA. However, only Portugal (69.8 per cent), Italy (67.8 per cent) Spain (66.1 per cent), the UK (53.2 per cent) and France (52.3 per cent) have more than half of their foreign population from countries beyond Europe.

The statistics in Table 3 reflect a complex set of geographical locations and migration histories. In the case of the UK, Ireland and Spain, proximity to a fellow EU member, together with a long history of population interchange, is clearly important (although this is not the case for Portugal as a destination). The situation in Belgium and Luxembourg reflects their geographical location, surrounded as they are by larger EU neighbours with open borders.

Table3: Foreign population in EU and EFTA countries, as of 1 january of various years

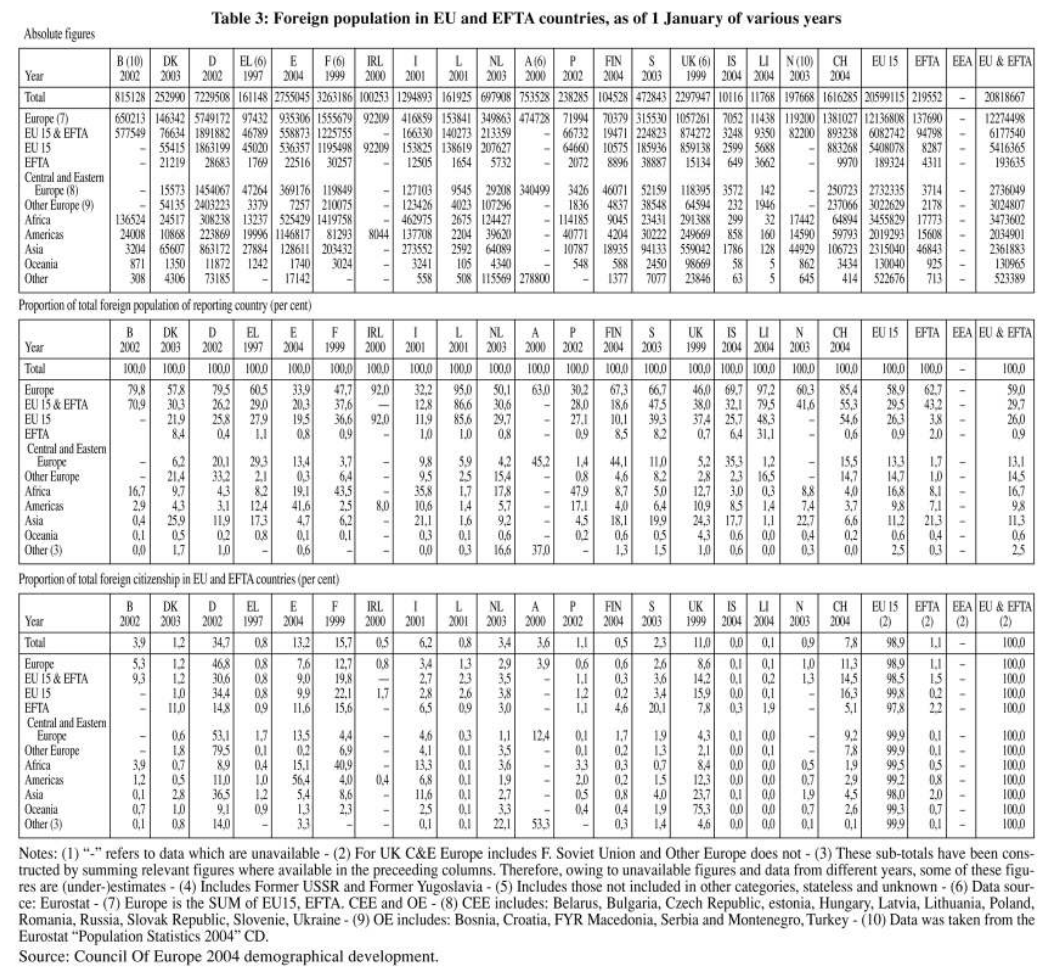



country. Africa is a particularly important source Portugal and France, and Italy reflecting earlier colonial ventures. The same is true for Belgium to a lesser extent. The Americas are important for Portugal (mainly Brazil) and especially Spain (mainly South America), and also for Greece, the UK (here especially the Caribbean) and Italy. Asia is a major source for the UK, Greece, Italy and the Scandinavian countries, though for different reasons and with emphases on different parts of that large and diverse continent. The UK receives Asian immigrants mainly from the Indian sub-continent, largely for settlement purposes; Italy's Asian contingent is mainly from South East Asia (particularly Filipinos); Greece's comes from proximate countries in the Middle East region, while asylum seekers have boosted Asian numbers in Scandinavian countries.

31 Analysis of the data in Table 3 with earlier years (see past reports to the Council of Europe) demonstrates, not unexpectedly, a stable distribution pattern that changes only slowly, as a result of net migration flows. It serves to emphasise that Western European countries may well have sharply divergent perspectives on migration, derived from their different foreign stocks.

Data availability on the nationalities of the foreign population in Central and Eastern Europe varies from country to country. The major part appears to comprise nationals from other Central and East European states, though the picture is clearly not static and is complicated by changes in numbers which result from changes in citizenship.

\section{Have There Been Major Changes in Europe's Migration Fields?}

What has been the outcome for the European migration system as a whole of the trends in migration flows and the processes creating them indicated above? Table 4 is an attempt to measure the degree of self containment within Europe of the migration fields of individual countries, based on the proportion of immigration and emigration flows to and from the regions listed and using the latest available data for those countries for which appropriate statistics exist. For most countries both immigration and emigration are mainly intra-European movements, the exceptions being Luxembourg, Slovenia, Spain and the UK in regard to immigration and Austria, Cyprus, Luxembourg, Slovenia, Spain and the UK. These countries tend to look beyond Europe. There is, therefore, a strong picture of self-containment, especially in Central and Eastern Europe. For most CEE countries listed in table 4, except Lithuania, Poland and Slovenia the main flows of both immigrants and emigrants are still within the region.

Revue européenne des migrations internationales, vol. 22 - n² | 2006 
Table 4: Percentage of total immigration/emigration by previous/next residence, 2004

\begin{tabular}{|l|r|r|c|c|c|c|c|c|c|c|}
\hline & \multicolumn{9}{|c|}{ Immigration } & \multicolumn{5}{c|}{ Emigration } \\
\cline { 2 - 11 } & EU \& EFTA & EU15 & Other Europe(2) & C\&E Europe(1) & Rest of World & EU \& EFTA & EU15 & Other Europe(2) & C\&E Europe(1) & Rest of World \\
\hline Austria & 18,3 & 17,4 & 22,4 & 24,3 & 34,3 & 14,5 & 13,5 & 15,1 & 16,4 & 53,6 \\
Belarus & 1,2 & 1,1 & 0,3 & 71,6 & 24,8 & 13,5 & 13,4 & 0,2 & 65,3 & 20,7 \\
Croatia & 13,6 & 11,4 & 69,7 & 3,1 & 13,6 & 29,4 & 28,8 & 46,0 & 2,7 & 22,0 \\
Cyprus & 51,1 & 50,9 & 1,4 & 21,9 & 24,2 & 16,4 & 16,2 & 1,4 & 15,2 & 65,5 \\
Czech Rep & 8,6 & 8,2 & 1,4 & 70,7 & 17,3 & 8,2 & 7,9 & 0,7 & 82,1 & 7,6 \\
Denmark & 45,1 & 34,2 & 2,4 & 10,4 & 39,1 & 51,0 & 40,1 & 1,4 & 6,9 & 38,0 \\
Finland & 43,9 & 37,9 & 3,7 & 22,6 & 29,6 & 64,9 & 58,1 & 1,0 & 11,9 & 22,2 \\
Germany & 17,7 & 16,3 & 10,9 & 39,0 & 32,1 & 27,2 & 24,5 & 12,4 & 28,9 & 31,3 \\
Latvia & 33,5 & 31,7 & 0,4 & 47,4 & 18,3 & 26,7 & 25,0 & 0,1 & 58,2 & 14,7 \\
Lithuania & 41,4 & 39,2 & 0,8 & 38,9 & 18,5 & 58,7 & 56,3 & 0,2 & 16,5 & 24,5 \\
Luxemburg & 24,2 & 23,9 & 0,1 & 0,5 & 74,4 & 44,6 & 43,3 & 0,2 & 0,8 & 51,0 \\
FYR Macedonia & 5,5 & 5,2 & 64,4 & 12,6 & 5,2 & 78,9 & 60,2 & 12,9 & 5,2 & 3,0 \\
Moldova & 5,9 & 5,4 & 15,0 & 36,6 & 42,5 & 7,2 & 7,2 & 0,1 & 73,4 & 19,4 \\
Netherlands & 34,8 & 33,5 & 6,0 & 11,0 & 48,0 & 55,6 & 53,5 & 3,9 & 3,2 & 37,2 \\
Norway & 38,9 & 37,6 & 3,8 & 14,1 & 42,9 & 59,1 & 56,6 & 1,4 & 3,5 & 35,7 \\
Poland & 45,8 & 44,9 & 1,2 & 21,2 & 31,2 & 81,7 & 81,0 & 0,1 & 0,5 & 17,6 \\
Slovakia & 22,0 & 20,7 & 10,9 & 46,6 & 20,3 & 42,1 & 36,6 & 0,6 & 45,4 & 11,9 \\
Slovenia & 5,5 & 4,9 & 6,1 & 0,4 & 88,0 & 17,5 & 16,0 & 6,2 & 0,6 & 75,7 \\
Spain & 15,8 & 15,0 & 0,1 & 19,9 & 63,6 & 20,2 & 18,1 & 0,1 & 4,7 & 72,9 \\
Sweden & 39,3 & 30,1 & 7,2 & 10,3 & 43,1 & 59,6 & 45,6 & 1,8 & 3,0 & 35,5 \\
UK & 15,1 & 14,4 & 0,7 & 12,4 & 71,7 & 30,3 & 29,4 & 3,5 & 2,3 & 63,1 \\
Ukraine & 1,4 & 1,4 & 0,5 & 57,6 & 30,9 & 16,6 & 16,5 & 0,1 & 62,6 & 19,5 \\
\hline
\end{tabular}

Notes: (1) CEE includes: Belarus, Bulgaria, Czech Rep, Estonia, Hungary, Latvia, Lithuania, Poland, Romania, Russia, Slovak rep, Slovenia, Ukraine - (2) OE includes: Bosnia-Herzegovina, Croatia, Cyprus, Former Yug FYR Macedonia, Malta, Serbia and Montenergo, Turkey.

b) Difference between percentage points of total immigration/emigration by previous/next residence, 1997 and 2004

\begin{tabular}{|c|c|c|c|c|c|c|c|c|c|c|}
\hline & \multicolumn{5}{|c|}{ Immigration } & \multicolumn{5}{|c|}{ Emigration } \\
\hline & EU \& EFTA & EU15 & C\&E Europe & Other Europe & Rest of World & EU \& EFTA & EU15 & C\&E Europe & Other Europe & Rest of World \\
\hline Austria & 35,7 & & 0,3 & & 6,7 & $-15,4$ & & $-30,3$ & & 36,0 \\
\hline Denmark & 1,4 & & 0,4 & & $-1,9$ & 1,3 & & $-4,8$ & & $-1,0$ \\
\hline Finland & $-0,1$ & & $-5,1$ & & 4,3 & $-12,8$ & & $-4,9$ & & 6,6 \\
\hline Germany & $-4,9$ & & 2,8 & & $-2,1$ & $-0,8$ & & $-29,1$ & & 7,4 \\
\hline Latvia & 28,6 & & $-40,1$ & & 10,7 & 21,5 & & $-86,9$ & & 6,9 \\
\hline Lithuania & 39,4 & & $-54,2$ & & 13,7 & 51,9 & & $-77,9$ & & 9,4 \\
\hline Netherlands & 2,8 & & 5,0 & & $-7,5$ & 5,6 & & 0,6 & & $-6,3$ \\
\hline Norway & $-15,7$ & & 6,4 & & 6,8 & 3,0 & & $-4,3$ & & $-1,7$ \\
\hline Slovenia & $-11,2$ & & $-0,2$ & & 81,7 & $-40,7$ & & 6,0 & & 65,0 \\
\hline Spain & $-30,2$ & & 17,5 & & 13,6 & 18,4 & & $-0,2$ & & $-25,0$ \\
\hline Sweden & 4,2 & & $-9,0$ & & 0,2 & $-1,3$ & & $-4,0$ & & 3,0 \\
\hline UK & $-18,6$ & & 10,2 & & 9,6 & $-4,0$ & & 0,4 & & 1,8 \\
\hline
\end{tabular}

Source: Common questionnaires

Comparison of the situation around 1997 and in 2004 shows some shifts in the migration fields. Figures 1 and 2 show change in the proportions of immigrants and emigrants for those countries with statistics at the two dates. The order of the countries in the graphs is that of the proportions going to or coming from EEA states. For the purposes of this exercise, CEE and Other European countries have been amalgamated. The objective is to determine if and to what extent Europe's migration fields have changed during the period. In the case of certain countries, at both ends of the graphs, shifts have been substantial. For example: both Latvia and Lithuania have greatly increased their interaction with the EEA while reducing it with the CEE countries; Spain's immigration field has shifted away from EEA states to include a higher proportion of inflows from CEE and the Rest of the World; Slovenia has dramatically increased its inflow from the Rest of the World. In contrast, most EEA countries record little geographical change over the period. Thus, it appears that any trend towards a more integrated European migration space as a whole affects some but by no means all countries. 
Figure 1: Difference between percentage points of total immigration by previous residence, 1997 and 2004

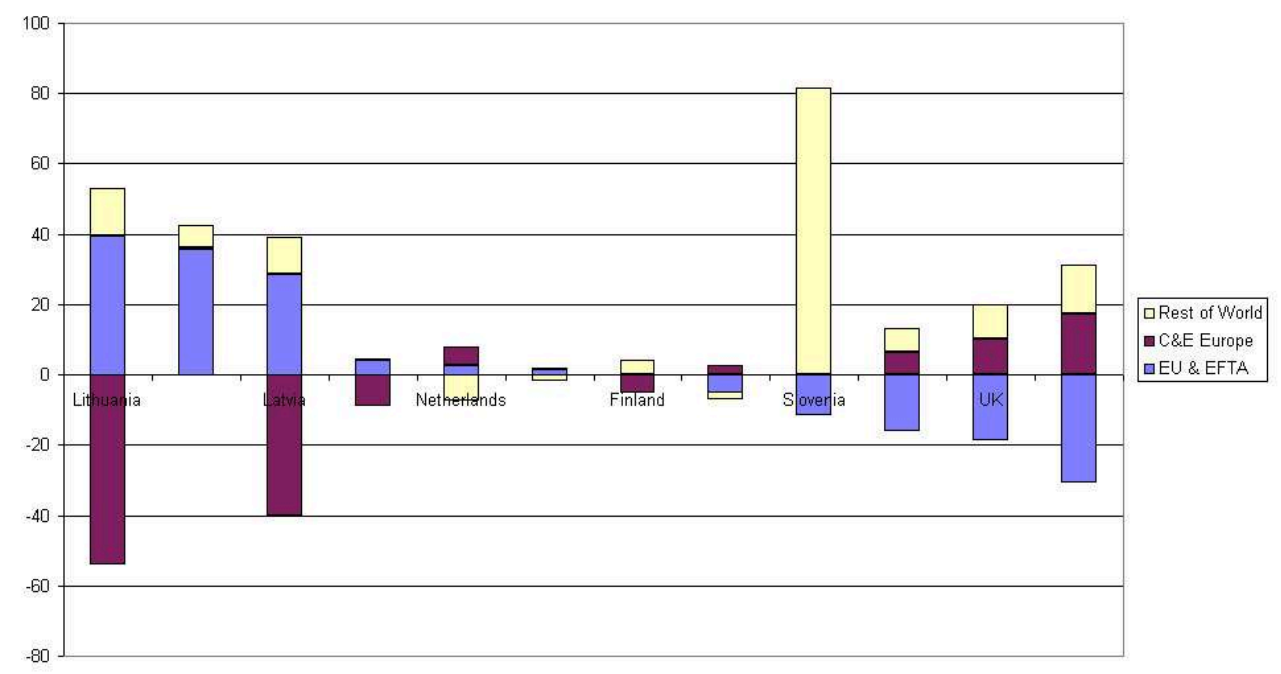

Figure 2: Difference between percentage points of total emigration by next residence, 1997and 2004

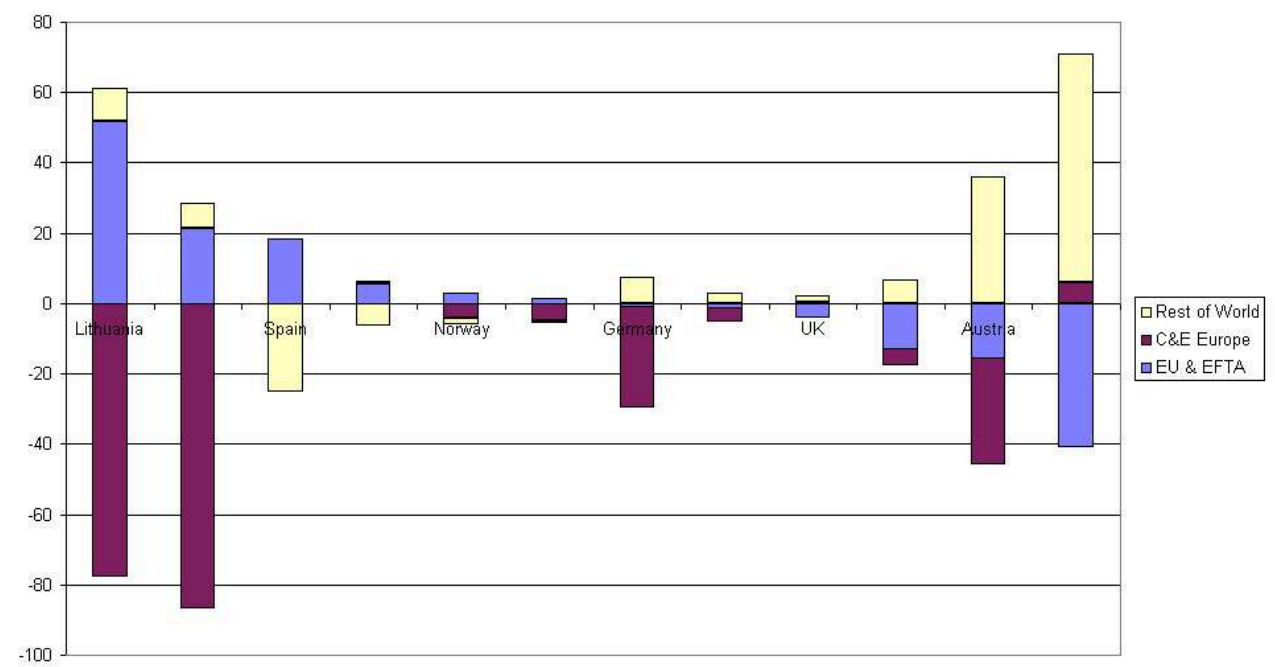

It is difficult to generalise from Table 4 and Figures 1 and 2 because of data interpretation problems for some countries, and the absence of statistics for many others. Nevertheless, three major conclusions may be drawn. First, there is some evidence of regional self-containment, especially for Central and Eastern European countries, in that the majority of exchanges are with elsewhere in Europe as a whole or its constituent parts. Further, while this regional self-containment has weakened in some cases since 1997, it does not appear substantially to have broken down. Second, there are marked differences in the migration fields of individual countries, reflecting a range of historical (such as post-colonial links) and geographical (especially proximity) processes. Finally, the patterns depicted reinforce the diversity of migration experience across Europe and also illustrate that the European migration system continues to interact strongly with the rest of the world. 


\section{What is the Impact of the Enlargement of the European Union?} workers which came into operation in the spring of 2004. During the period May 2004December 2005 there were 345,000 applications to the WRS, most of which were approved. Poles were the main group (59 per cent), followed by Lithuanians (13 per cent) and Slovaks (11 per cent). Most were young, 83 per cent aged 18-34, with a male:female ratio of 57:43. The largest occupation group was process operatives (in factories), with 36 per cent, followed by kitchen and catering assistants (10 per cent). Comparison with non-EEA nationals entering through the work permit system is revealing: around 80 per cent of this group were in highly skilled occupations, a similar proportion of WRS applicants were in low-skilled occupations. Hence, the two groups were complementary (Salt, 2005). On the whole, the effect of the new A8 labour force on the UK economy seems to have been broadly positive, if modest, with little evidence so far that it has contributed to a rise in claimant unemployment (Gilpin, et al., 2006).

\section{Is Asylum Seeking Increasing?}

Much of the discussion about the scale of migration into and within Europe separates out asylum seekers from 'normal' (predominantly labour and family reunion) migration flows. There are sound reasons for this. Not only are the motivations of the two sets of 
moves different, but the data are also collected and presented differently. However, the distinction between the two has become increasingly blurred. Many asylum seekers are not in need of protection and are attempting to migrate for economic and/or family reasons, while the statistical distinction is no longer clear. One study in the UK found that facilitators/smugglers were primarily responsible for the choice of destination (Gilbert and Koser, 2004). Asylum policy and reception vary in importance between countries and this information is used by facilitators as well as by individual asylum seekers.

Table 5: Asylum applications in selected European countries, 1995-2004 (thousands)

\begin{tabular}{|l|r|r|r|}
\hline & 1995 & 2000 & 2004 \\
\hline a) Western Europe & & & \\
Austria & 5,9 & 18,3 & 24,7 \\
Belgium & 11,4 & 42,7 & 15,4 \\
Denmark & 5,1 & 12,2 & 3,2 \\
Finland & 0,9 & 3,2 & 3,9 \\
France & 20,4 & 38,8 & 61,6 \\
Germany & 127,9 & 78,6 & 35,6 \\
Iceland & 0,0 & 0,0 & 0,1 \\
Ireland & 0,4 & 11,1 & 4,8 \\
Liechtenstein & - & 0,0 & 0,1 \\
Luxembourg & 0,4 & 0,6 & 1,6 \\
Netherlands & 29,3 & 43,9 & 9,8 \\
Norway & 1,5 & 10,8 & 8,0 \\
Sweden & 9,1 & 16,3 & 23,2 \\
Switzerland & 17,0 & 17,6 & 14,3 \\
United Kingdom & 55,0 & 98,9 & 40,2 \\
\hline Totals (Western Europe) & 284,3 & 393 & 246,5 \\
\hline b) Southern Europe & & & \\
Greece & 1,3 & 3,1 & 4,5 \\
Italy & 1,7 & 15,6 & 10,0 \\
Portugal & 0,5 & 0,2 & 0,1 \\
Spain & 5,7 & 7,9 & 5,4 \\
\hline Totals (Southern Europe) & 9,2 & 26,6 & 20 \\
\hline c) Central and Eastern Europe & & & \\
Bulgaria 0,5 & 1,8 & 1,1 & \\
Czech Republic & 1,4 & 8,8 & 5,5 \\
Estonia & - & - & 0,0 \\
Hungary & 0,1 & 7,8 & 1,6 \\
Latvia & - & - & 0,0 \\
Lithuania & - & 0,2 & 0,1 \\
Poland & & \\
Romania & 0,8 & 4,6 & 8,1 \\
Slovakia & - & 1,4 & 0,7 \\
Slovenia & 0,4 & 1,6 & 11,4 \\
\hline Totals (Central and Eastern Europe) & 3,2 & 3,2 & 1,2 \\
\hline & & & 29,7 \\
\hline
\end{tabular}

Source: Governments, UNHCR. Compiled by UNHCR (Population Data Unit)

Inflows of asylum seekers to Europe as a whole have fluctuated in total and between destination countries. In 1995 Western Europe received 284,300 applications from asylum seekers. The number rose to 393,000 in 2000 , mainly because of trouble in the Balkans, before falling back to around 246,500 in 2004. Overall, the upward trend in numbers changed around 2003. In 2004 the total number of applications reached the lowest level since 1996. Some countries had particularly large falls since 2000, notably the Netherlands (-78 per cent), Denmark (-74 per cent), Belgium (-64 per cent, the UK ( -60 per cent), Ireland ( -57 per cent) and Germany ( -55 per cent).

Only five countries in Western Europe showed increases in the numbers of requests for asylum since 2000 (Austria, Finland, France, Luxembourg and Sweden). In Southern Europe, all countries except Greece had fewer applications in 2004 when compared with 2000. In Eastern Europe only Poland and Slovakia had increased numbers from 2000 to 2004 (Table 5).

Explanation of these patterns is complex and the falls reflect a changing situation within Europe and globally. The perturbations in the Balkans had largely subsided, 
cease fires had occurred in some troubled parts of the world (e.g. Sri Lanka) and other countries were deemed now to be "safe" (Afghanistan, Iraq). Several destination countries have also put into operation asylum reduction models designed to interdict flows, curtail administrative processes and reduce benefits to asylum seekers

There have also been significant changes in asylum pressure, measured in terms of number of asylum requests per 10,000 population (Table 6). For the EU and EFTA states as a whole, pressure increased from 4.6 in 1985 to a peak of 18.4 in 1992 caused mainly by conflict in former Yugoslavia. There was then a fall to 11.7 in 1999 and a further fall to 6.8 in 2004. The countries experiencing the greatest pressure in 2004 are small in population, Luxembourg, Austria, Liechtenstein and Sweden. In the case of Ireland, asylum requests have risen from very small numbers since the early 1990s, partly in response to the strength of its economy, partly to its citizenship law. At the other end of the scale, Portugal, Iceland, and Spain have low asylum pressure, reflecting their geographical position, their relative popularity as destinations and their asylum laws. The countries with the largest numbers of applications, France, Germany and the UK, have relatively modest levels of pressure. What is not clear from Table 6, however, is how far these numbers are affected by registration of asylum flows.

Table 6: Asylum applications in EU and EFTA countries 1992, 1999 and 2004 (thousands)

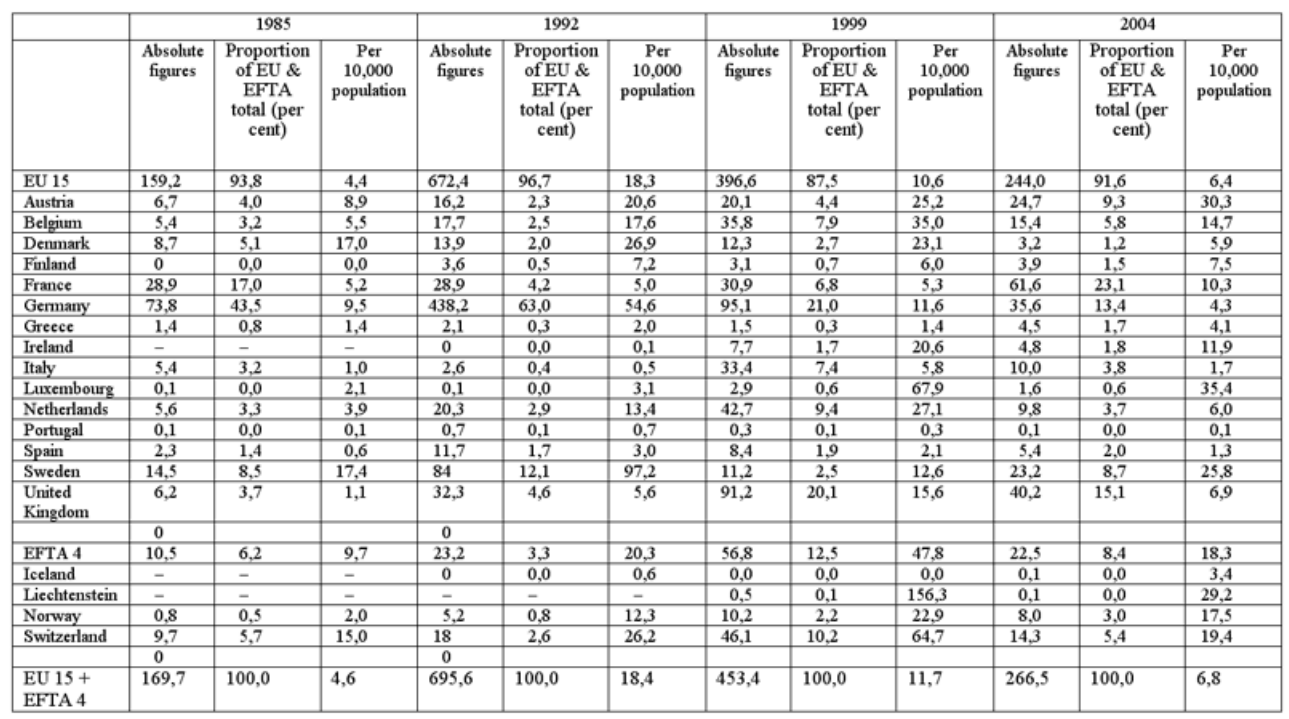

Notes:

EFTA: 1985, 1999 estimated.

EU15: 1985 estimated.

Source: UNHCR, Eurostat.

For most countries in Central and Eastern Europe, the 1990s was a period of evolution for migration and asylum legislation and for statistical recording. In most cases, countries of the region were senders rather than receivers of asylum seekers. Even when they started to receive applications, most were a device for staying in the country prior to an attempt to get to Western Europe rather than being genuine requests. There is some recent evidence that asylum seekers are now targeting Central and Eastern European countries for settlement because of their political freedom, economic growth and membership of the EU. In effect, they too have become attractive destinations. 
Data on asylum seeking in Central and Eastern Europe are still very partial, and for the most part the numbers recorded are low (Table 5). In 2004 there were a total of 29,700 applications for asylum in the eight countries listed, a significant fall from the 35,400 registered in the same countries in 2001.

\section{Is Irregular Migration Increasing?}

Attempts have been made in some countries to estimate the size of the irregular population, using a variety of methods and assumptions, and they should be regarded as indicative at best (Baldassarini, 2001; Poulain, 1998; Piguet and Losa, 2002; Van der Leun, Engberson and Van der Heijden, 1998). Several amnesty programmes in Mediterranean countries have shown the numbers to be considerable. Analysis of regularisations up to the beginning of 2000 (Apap et al., 2000) suggests that the total number regularised in the programmes of Greece, France, Spain and Italy was 1.75 million. Since then further amnesties in Southern Europe have resulted in approaching several hundred thousand more applications. These regularisation processes have been helpful to achieve a better understanding of irregular migration in Europe. But to know the size of the illegal population stock across Europe or in individual countries remains extremely difficult if not impossible.

As the issues raised by irregular migration, especially migrant trafficking and human smuggling, have risen on the political agenda, so the enormous complexities inherent in them have become more apparent. In a very real sense, however, the rhetoric has run ahead of the research. There is a fundamental lack of hard evidence relating to most aspects of the problem. Methodologies for studying both traffickers/smugglers and their clientele are barely developed, the theoretical basis for analysis is weak and, most importantly, substantial empirical surveys are few and far between. Slowly, these deficiencies are being met. For example, two IOM studies have thrown light on the geographically pivotal role of Turkey with respect to irregular migration (Içduygu, 2003) and trafficking in women (Erder and Kaska, 2003). The ICMPD now carries out an annual survey and analysis of border management and apprehension data (ICMPD, 2004, 2005).

Until recently few studies (Juhasz, 2000; Klinchenko et al, 2000) have attempted to use border crossing data to analyse the scale of the flow of illegal migration. The nature of such data raises several problems, but they do give useful indications of trends in irregular migrations. In 2004 about 116,100 apprehensions were recorded at the borders of the CEE countries surveyed by the ICMPD and listed in Table 7 (ICMPD, 2005). This represents a considerable reduction on the figures for 2001 and 2002. Based on only those 13 countries for which there were data in 2004 the downward trend has been slowing, from 218,900 in 2001, 154,100 in 2002, 119,000 in 2003 and 116,100 in 2004. Relatively high numbers of apprehensions in 2004 occurred at the borders of Turkey, and the Czech Republic. In most cases the trend since 2001 has been downward, although a few countries did show small increases. 
Table 7: Irregular Migration

a) Number of border violation related apprehensions in selected Central and Eastern European countries, 2001-04

\begin{tabular}{|l|r|r|r|r|c|c|c|}
\hline & 2001 & 2002 & 2003 & 2004 & $\begin{array}{c}\% \text { change } \\
2001-02\end{array}$ & $\begin{array}{c}\text { \% change } \\
2002-03\end{array}$ & $\begin{array}{c}\% \text { change } \\
2003-04\end{array}$ \\
\hline Armenia & - & 15,8 & 19,0 & - & - & 20,5 & - \\
Azerbaijan & 7,6 & 8,3 & 3,8 & 2,9 & 8,6 & $-53,7$ & $-24,5$ \\
Bosnia Herzegovina & $\overline{6}$ & 0,4 & 1,0 & 0,9 & - & 145,4 & $-8,6$ \\
Bulgaria & 6,0 & 6,5 & 5,1 & 6,0 & 8,2 & $-20,4$ & 15,9 \\
Croatia & 17,4 & 5,9 & 4,2 & - & $-66,3$ & $-28,1$ & - \\
Cyprus & 0,2 & 0,7 & 3,7 & 2,6 & 298,4 & 413,9 & $-31,3$ \\
Czech Republic & 23,8 & 14,7 & 13,2 & 10,7 & $-38,2$ & $-10,4$ & -19 \\
Hungary & 16,6 & 16,0 & 13,5 & - & -4 & $-15,3$ & - \\
Latvia & 7,8 & 9,7 & 8,6 & - & 24,2 & -12 & - \\
Lithuania & 1,4 & 0,8 & 0,8 & 0,9 & $-41,2$ & 0,8 & 17,9 \\
Poland & 5,2 & 4,3 & 5,1 & 5,8 & $-18,2$ & 18,6 & 13,8 \\
Romania & 32,0 & 3,1 & 2,1 & 1,5 & $-90,4$ & $-30,8$ & $-29,9$ \\
Yugoslavia & 1,3 & 0,8 & 0,9 & 1,1 & $-35,6$ & 3,9 & 22,2 \\
Slovak Republic & 15,5 & 15,2 & 12,5 & 8,3 & -2 & -18 & $-33,3$ \\
Slovenia & 20,9 & 6,9 & 5,0 & 5,7 & -67 & $-27,2$ & 13,2 \\
Turkey & 92,4 & 82,8 & 56,2 & 61,2 & $-10,3$ & $-32,1$ & 8,9 \\
Ukraine & 12,6 & 9,6 & 9,6 & 8,5 & $-23,6$ & 0 & $-11,5$ \\
\hline
\end{tabular}

Source: ICMPD.

b) Enforcement action against irregular migration in selected Western and Central European countries, 1995-2004 (thousands)

\begin{tabular}{|c|c|c|c|c|c|c|c|c|c|c|}
\hline & 1995 & 1996 & 1997 & 1998 & 1999 & 2000 & 2001 & 2002 & 2003 & 2004 \\
\hline $\begin{array}{c}\text { Apprehensions at border } \\
\text { Germany }\end{array}$ & 29,6 & 27,0 & 35,2 & 40,2 & 37,8 & 31,5 & 28,6 & 22,6 & 20,0 & 18,2 \\
\hline $\begin{array}{c}\text { Austria } \\
\text { Italy (1) } \\
\text { Switzerland }\end{array}$ & 134,7 & 134,0 & 80,7 & 25,5 & 24,7 & 19,1 & 17,6 & - & 2,4 & 26,3 \\
$-10,4$ & 9,9 & $-9,8$ & 31,7 & 37,7 & 27,2 & 34,0 & 31,8 & 25,7 & - \\
9,1 & 10,1 & 8,8 & 8,7 & 8,4 & 10,3 \\
\hline $\begin{array}{c}\text { Enforcement actions against } \\
\text { illegalentry of entry }\end{array}$ & & & & & & & & & & \\
United Kingdom & 10,8 & 14,6 & 14,4 & 16,5 & 21,2 & 47,3 & 69,9 & 48,1 & - & 36,6 \\
\hline
\end{tabular}

Notes: (1) Figures are for July to June - i.e. 1998 figures refer to July 1998 to June 1999. European countries. Those in Table $7(b)$ have been compiled from several sources rather than one survey and they record different sorts of border action against irregular migration. The numbers vary from country to country. They fluctuate from one year to another but the most recent data generally show declines from the peaks of earlier years.

52 The trends in Table 7 may be explained in a number of ways. The fall in numbers of apprehensions may be because there are fewer irregular migrants attempting to cross borders. This may be the result of better border management which has deterred attempted crossings. It may in some cases be a consequence of a slackening in visa regimes as was the case for Romanian travellers after 2002 (ICMPD, 2004). There may also have been diversion of flows into other routes and channels: this might explain the big increase in apprehensions in Cyprus in 2003 and frequent press reports of a surge in

Revue européenne des migrations internationales, vol. 22 - n² | 2006 
apprehensions in the Canary Islands in 2004-05. On the face of it, however, the data here do not support the view that irregular migration flows are on the increase; indeed, they suggest the reverse.

\section{Conclusions}

53 In this paper, we have tried to identify the chief characteristics of and the main changes in flows and trends in international migration in Europe in the last decade. The answers to the questions raised are not easy given the difficulties related to the data. Generalisations are also difficult in a continent with a highly differentiated physical and human geography. The general picture with regard to stocks of foreign population is one of diversity across Europe. But it is also a picture of relative stability. Unlike earlier fears of mass migrations, recorded migration is now relatively stable, with the exception of the incorporation of large numbers of amnestied former illegal migrants in some countries. Many countries have shown decreasing numbers of requests for asylum since 2000, and the available data in irregular migration flows do not support the view that irregular migration is on the increase.

What does seem to be emerging is a more integrated European economic and social space, characterised by both new and older forms of mobility. There is now widespread circulation of people in informal and short-term movements, but there are also some remarkable parallels with the guestworker phase in the decades after World War II.

Politically much as changed in 10 years. Today, the burning issues are no longer those of ten years earlier. Western European countries are growing more concerned with the challenges of their ageing demographies and the role that international migration might be called upon to play. Currently migration is the most important component of population change in 27 (60 per cent) of the 45 countries for which data are available, for the period 2003-04. There is also a realisation that the demography of immigrants is an important element in future population developments in Europe (Haug, Compton and Courbage, 2002).

In the medium term the biggest issue is the effects of the new round of $\mathrm{EU}$ enlargement, which has brought ten countries and 75 million people into the Union. Past experience and several studies of the prospective enlargement have failed to indicate that further large scale movements from the new to the existing member states will occur, although there is bound to be some redistribution of population as the economies of the Union become more integrated. What may confidently be anticipated is that the attraction of the European theatre as a whole will increase. 


\section{BIBLIOGRAPHY}

APAP J. et al. (2000) Rapport de synthese sur la comparaison des regularisations d'etrangers illegaux dans l'Union Europeenne. 23-82 in De Bruycker, P., (ed.), De Bruycker, P., (Ed.) Regularisations of Illegal Immigrants in the European Union, Brussels, Bruylant.

BALDASSARINI A. (2001) Non Regular Foreign Input of Labour in the New National Accounts Estimates. OECD Meeting of National Accounts Experts, Paris. STD/NA(2001)30.

CECCAGNO (2003) “New Chinese Migrants in Italy" in International Migration, 41(3) 2003. 187-214. DOLVIK J. and ELDRING L. (2006) Status Report January 2006: The Impact of EU Enlargement on Labour Mobility to the Nordic Countries. Semi-annual Memo for a Working Group under the Labour Market Committee of the Nordic Council of Ministers. Oslo.

ERDER S. and KASKA S (2003) Irregular Migration and Trafficking in Women: the Case of Turkey, Geneva: IOM.

FREJKA T. (ed.) (1996) International Migration in Central and Eastern Europe and the Commonwealth of Independent States, Geneva and New York: United Nations.

GARSON J.-P., REDOR D. and LEMAITRE G. (1997) "Regional Integration and the Outlook for Temporary and Permanent Migration in Central and Eastern Europe" in Biffl, G. (ed.), Migration Free Trade and Regional Integration in Central and Eastern Europe, Vienna: Verlag Österreich.

GIESE K. (2003) "New Chinese Migration to Germany: Historical Consistencies and New Patterns of Diversification within a Globalised Migration Regime" in International Migration, 41(3). 155-186. GILBERT A. and KOSER K. (2004) Information dissemination to potential asylum seekers in countries of origin and/or transit, Research findings 220, London: Home Office.

GILPIN N., HENTY M., LEMOS S., PORTES J. and BULLEN C. (2006) The Impact of Free Movement of Workers from Central and Eastern Europe on the UK Labour Market. Department for Work and Pensions, Working Paper 29. London.

HAGOS M. (2005) SOPEMI Report for Sweden. Paris, OECD.

HAUG W., COMPTON P. and COURBAGE Y. [eds] (2002) The Demographic Characteristics of Immigrant Populations, Strasbourg: Council of Europe.

HUGHES G. (2005) International Migration and Ireland, the report of the Irish SOPEMI correspondent to the OECD, Paris: OECD.

IÇDUYGU A. (2003) Irregular Migration in Turkey, IOM Migration Research Series, No. 12. Geneva: IOM.

ICMPD (2004) 2003Year Book on illegal migration, human smuggling and trafficking in Central and Eastern Europe, Vienna: ICMPD.

ICMPD (2005) 2004 Year Book on illegal migration, human smuggling and trafficking in Central and Eastern Europe, Vienna: ICMPD.

JUHASZ J. (2000) Migrant Trafficking and Human Smuggling in Hungary, 167-232 in IOM, Migrant Trafficking and Human Smuggling in Europe. Geneva, IOM.

KLINCHENKO T. (2000) “Migrant Trafficking and Human Smuggling in Ukraine”, 329-416 in IOM, Migrant Trafficking and Human Smuggling in Europe. Geneva, IOM. 
Van der LEUN J.P., ENGBERSEN G., van der HEIJDEN P. (1998) Illegaliteit en criminaliteit. Schattingen, aanhoudingen en uitzettingen Rotterdam: Erasmus University.

MAI N. and SCHWANDER-SIEVERS S. (2003) “Albanian migration and new transnationalisms" in Journal of Ethnic and Migration Studies, 29(6). 939-948.

MICHALON B. (2004) "Playing on ethnicity to be there and here: The three paradoxes of 'ethnic migrations" in International migration in Europe: new trends, new methods of analysis, papers from the 2nd Conference of the EAPS Working Group on International Migration in Europe Rome, Italy, 25-27 November 2004.

OKOLSKI M. (1998) “Regional Dimension of International Migration in Central and Eastern Europe", GENUS 54:1-26.

PERALDI M. (2004) "Algerian routes: a new perspective on migrant and social mobilities" in International migration in Europe: new trends, new methods of analysis, papers from the 2nd Conference of the EAPS Working Group on International Migration in Europe Rome, Italy, 25-27 November 2004.

PIGUET E., LOSA S. (2002) Travailleurs de l'ombre?Demande de main-d'œuvre du domaine de l'asile et ampleur de l'emploi d'étrangers non déclarés en Suisse. Seisomo: Zurich.

POULAIN M. (1998) “Belgium” in Delauney, D. and Tapinos, G. La mesure de la migration clandestine en Europe, Population and Social Conditions Working Paper 3/1998/E/no. 7, Luxembourg: Eurostat.

POTOT S. (2004) “The Romanian circulatory migration: a case study" in International migration in Europe: new trends, new methods of analysis, papers from the 2nd Conference of the EAPS Working Group on International Migration in Europe Rome, Italy, 25-27 November 2004.

SALT J. (2006) Current Trends in International Migration in Europe. Report to the Council of Europe.

SALT J. (2005) International Migration and the UK: Report of the UK SOPEMI Correspondent to the OECD. Paris, OECD.

SALT J., SINGLETON A. and HOGARTH J. (1994) Europe's international migrants: data sources, patterns and trends.HMSO, London.

\section{AUTHORS}

\section{JOHN SALT}

Professor in Geography, Director of the Migration Research Unit, University College London. Email: jsalt@geog.ucl.ac.uk

\section{JOSÉ CARLOS ALMEIDA}

Post-Doctoral Research Fellow, Migration Research Unit, University College London. Email: jose.almeida@ucl.ac.uk 